\title{
2o. Refik Halit Karay’ın “Eskici” öyküsü ve coğrafya algısında değişim
}

\section{Selçuk TÜRKYILMAZ1}

\begin{abstract}
APA: Türkyılmaz, S. (2021). Refik Halit Karay'ın "Eskici” öyküsü ve coğrafya algısında değişim. RumeliDE Dil ve Edebiyat Araştırmaları Dergisi, (22), 353-361. DOI: 10.29000/rumelide.886043.
\end{abstract}

\section{$\ddot{\mathbf{O} z}$}

$\mathrm{Bu}$ makalede Osmanlı coğrafyasının dağılması, coğrafî parçalanma ve bu coğrafyanın bir bölümünde kurulan manda yönetimlerle birlikte ortaya çıkan birtakım meseleler Refik Halit Karay’ın "Eskici” adlı öyküsü temel alınarak incelenecektir. Birinci Dünya Savaşı’ndan sonra kolonyalist yönetim biçimleri terk edilmiş ve bunun yerine manda yönetimler kurulmuştu. Yeni yönetim modeli de sömürgecilik sistemi içinde yer almaktaydı. Karay, 1922-1938 yılları arasında Fransız ve İngiliz manda yönetimleri altındaki Filistin ve Suriye'de sürgün hayatı yaşamıştır. Yazarın yeni sömürge modelini tecrübe etmesi ve öyküde anlatılan olayların büyük ölçüde manda yönetimi altındaki Filistin'de geçmesi, incelediğimiz meseleler açısından "Eskici”yi önemli hâle getirmiştir. Öykünün kahramanı Hasan, yazar gibi İstanbul'dan göç etmek zorunda kalmıştır. Bu durum öykünün tahlili açısından dikkat çekici bir benzerliktir. Yazarın gözlem ve izlenimlerinin “Eskici”ye yansıdığını söyleyebiliriz. Osmanlı İmparatorluğu'nun Araplarla meskûn bölgeleri İngiltere ve Fransa'nın yönetimine geçtikten sonra birçok yeni sorun ortaya çıkar. Arap milliyetçiliği, sömürgecilik ve emperyalizm gibi kavramlar Osmanlı yönetimi ile ilişkilendirilecek şekilde kullanılır. Bunu da sömürgecilik tarihinin yakın coğrafyamızdaki yansımaları olarak görebiliriz. Sömürgeciliğin yol açtığı sorunları ortaya çıkarmaya; imparatorluk, kolonyalizm ve emperyalizm gibi kavramları karşılaştırılmalı olarak incelemeye imkân vermesi bakımından "Eskici” istisnâ̂ bir örnektir. Hasan'ın zorunlu bir göçmen olarak macerası da dikkatimizi imparatorluk coğrafyasındaki nüfus hareketlerine yöneltir. "Eskici”nin Osmanlı coğrafyasının dağılma süreciyle alakalı birtakım sorulara cevap bulmamıza da imkân vereceğini söyleyebiliriz. Bu da coğrafyamızla alakalı yargıları yeniden sorgulamak anlamına gelir. Bu makalenin imparatorluk, sömürgecilik ve oryantalizm tartışmalarına önemli bir katkı sağlayacağı düşünülmektedir.

Anahtar kelimeler: Refik Halit Karay, "Eskici”, imparatorluk, kolonyalizm, coğrafya algısında değişim

\section{The "Eskici" story of Refik Halit Karay and the change in the perception of geography}

\begin{abstract}
In this article, the disintegration of the Ottoman geography, geographical fragmentation and in some part of this geography by the establishment of mandate governments the emerged issues will be examined on the basis of Refik Halit Karay's story "Eskici". After World War 1st, colonialist regime forms were abandoned and mandate governances were established instead. The new governance model was also included in the colonial system. Between 1922-1938 years, Karay lived in exile in Palestine and Syria under the French and British mandate. Experiencing the author's new
\end{abstract}

Dr. Öğr. Üyesi, İzmir Katip Çelebi Üniversitesi, Sosyal ve Beșeri Bilimler Fakültesi, Türk Dili ve Edebiyatı Bölümü (İzmir, Türkiye), selcuk.turkyilmaz@hotmail.com, ORCID ID: oooo-0oo2-1953-9394 [Araştırma makalesi, Makale kayıt tarihi: 26.10.2020-kabul tarihi: 20.03.2021; DOI: 10.29000/rumelide.886043]

Adres | Address

RumeliDE Dil ve Edebiyat Araşttrmaları Dergisi $\quad$ RumeliDE Journal of Language and Literature Studies Osmanağa Mahallesi, Mürver Çiçeği Sokak, No:14/8 Osmanağa Mahallesi, Mürver Çiçeği Sokak, No:14/8

Kadıköy - İSTANBUL / TÜRKIYE 34714 Kadıköy - ISTANBUL / TURKEY 34714 e-posta: editor@rumelide.com

e-mail: editor@rumelide.com,

tel: +90 505 7958124, +90 2167730616 phone: +90 505 7958124, +90 2167730616 
colonial model and the fact that what is told in the story mostly took place in the mandate rule in Palestine, made "Eskici" important among the issues we examined. The hero of the story Hasan, as a writer was obliged to migrate from Istanbul. This is a remarkable similarity in terms of the analysis of the story. We can say that the author's observations and impressions are reflected in "Eskici". After the Arabs inhabited regions of the Ottoman Empire came under the governance of Britain and France, various new problems arise. Concepts such as Arab nationalism, colonialism and imperialism are used to be related with Ottoman governance. We can see this as the reflections of the colonial history in our near geography. To reveal the problems caused by colonialism; allowing and paving the ground for a comparative study of concepts such as empire, colonialism and imperialism "Eskici" is an exceptional example. Hasan's adventure as a forced immigrant turns our attentions to the population movements in the geography of the empire. We can say that, "Eskici" will allow us to find answers to some questions about the disintegration process of the Ottoman geography. This will also pave the ground to questioning of stereotype judgments about our geography. It is considered that this article will provide an important contribution to the debates on empire, colonialism and orientalism.

Keywords: Refik Halit Karay, "Eskici”, empire, colonialism, change in geography perception

\section{Giriş}

Osmanlı Devleti, Birinci Dünya Savaşı'nda mağlup oldu ve bu mağlubiyetle birlikte coğrafyamızda birçok değişim yaşandı. Değişim, devletin hâkim olduğu coğrafyanın tamamı için geçerliydi ve Türkiye bu değişimi bugünkü coğrafyasına geçiş yaparak yaşadı. Libya'nın İtalyanlar tarafından işgali ile başlayan süreç, Balkanlarda toprak kaybıyla devam etmiş ve I. Dünya Savaşı sona erdiğinde Devlet-i Âliye'nin coğrafî sahası, bütünlüğünü ve devamlılığını kaybetmişti. Bu, kısa sayılabilecek zamanda büyük ve sarsıcı bir değişim anlamına gelir. Savaş yıllarını, Türkiye açısından bütün cephelerden Anadolu'ya çekilme süreci olarak tanımlayabiliriz. Bu dönemde Türklerle birlikte diğer Müslüman unsurların Anadolu'ya göçü, üzerinde durulması gereken bir meseledir. Göç sürecini Kırım’ın kaybı veya 1877-78 Osmanlı Rus Harbi ile başlatabiliriz.

Osmanlı Devleti'nin gerileme döneminde Müslüman ahali Türklerle birlikte Türkiye Cumhuriyeti’nin kuruluşuna kadar Anadolu'ya göç etmiştir. Göç, tarihe 93 Harbi adıyla geçen savaştan sonra çok daha yoğunlaşmıştır. Kısa sayılabilecek bir zamanda yaşanan büyük ölçekli coğrafî değişim veya daralma, yaşayanları derinden etkilemiş olmalıdır. Bu hızlı değişim, birtakım siyasî ve ideolojik kavramların ortaya çımasına yol açtı̆̆ı gibi edebî eserlere de yansımıştır. Dolayısıyla edebî eserlerdeki etkilerini ortaya çıkararak değişim sürecini ve sonuçlarını belirleyebiliriz. Böylelikle zihniyet biçimleri, davranışlar, kavramlar, fikirler vb. etkilere odaklanmak mümkün olacaktır. Örneğin Ahmet Mithat Efendi ile Mehmet Akif ve Yahya Kemal'in coğrafya algıları birbirinden farklıdır. Namık Kemal'in Vatan yahut Silistre ve Ahmet Mithat Efendi'nin Musullu Süleyman adlı romanlarındaki Silistre ve Musul'un gösterdiği coğrafî genişliği 1930'ların edebî eserlerinde bulamayız. Akif, Çanakkale Şehitlerine başlıklı şiirini Arap çöllerinde yazdıktan (Kandemir, 1991: 348) çok kısa bir zaman sonra İstiklal Marşı'nı kaleme alır. Aynı şairin kaleminden çıkmış bu iki şiirde bahsettiğimiz coğrafî değişimi görebiliriz. Coğrafî değişim, şair ve yazarların coğrafya algısı üzerinde derin izler bırakmıştır. Örneğin İstiklal Marşı'nda yeni bir vatan algısı öne çıkar. Bu, Arap coğrafyasını yakından bilen biri için şaşırtıcı ve üzücü bir sonuç olsa gerektir.

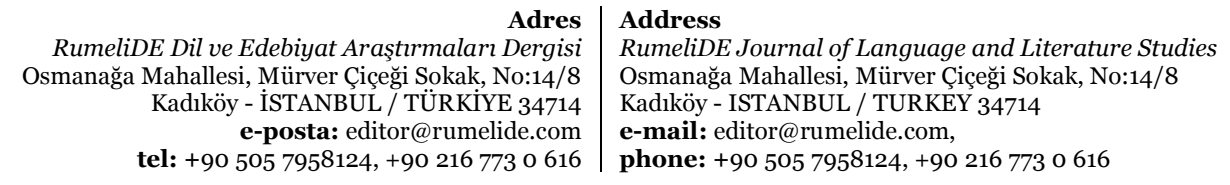

RumeliDE Dil ve Edebiyat Araşttrmaları Dergisi esi, Mürver Çiçeği Sokak, No:14/8 tel: +90 505 7958124, +90 2167730616 
Türkiye, Osmanlı'dan Cumhuriyet'e sancılı ve sarsıcı olayların gölgesinde geçti. Bu dönem imparatorluktan ulus devlete geçiş olarak düşünülürse sorunların yaşanması tabiî bir durumdur. Fakat geçişi tek başına incelediğimizde bu sorunlardan bir kısmının dikkati çekmeyeceğini düşünebiliriz. İmparatorluktan millî devletlere geçiş sorunlarını yaşayan başka devletlerle karşlaş̧ırdığımızda ise bugün dikkati çekmeyen meseleler öne çıkacaktır. Bu açıdan edebî eserleri bir veri kabul edip karşılaştırmalı incelemek, dikkat çekmeyen sorunların fark edilmesine imkân tanıyabilir.

\section{İmparatorluk, kolonyalizm ve hegemonya}

Edward Said özellikle edebî eserlerden hareketle oryantalizme yönelik güçlü bir eleştirel yaklaşım geliştirmiş, Batı'nın Doğu üzerinde kurduğu tahakkümün dayanaklarını izah ederken bilgi ve iktidar ilişkisi üzerinden ilgi çekici sonuçlara ulaşmıştır (Said, 1991: 85-124). Sonraki çalışmalarında da edebî eserleri temel alarak imparatorluk, kolonyalizm, emperyalizm ve hegemonya kavramlarını tartışmıştır (Said, 1998: 37-91). Sömürgecilik sonrası eleştirel yaklaşımlarda da benzer kavramlar üzerinde durulmuştur (Young, 2016: 19-77). Said (1991) ve Young (2016), sömürgecilik bağlamında imparatorluk ana vatanı ile sömürge toprakları arasındaki ilişkilere özel bir önem atfetmişlerdir. Said, Batı edebiyatına odaklandığı için, sömürge toplumlarının entelektüel hareketliliğini geri planda tutmuş, Young ise Avrupamerkezci bakış açısının dışına çıkan ideolojik yaklaşımların üzerinde durmuştur. Bu suretle hegemonyanın oluşumu ve sürdürülmesine dayanak oluşturan metinlerle sömürgecilik karşıtlığı bağlamında üretilen edebiyat öne çıkmıştır. Fakat Batı Avrupa sömürgeci devletleriyle mücadele tarihi içinde Osmanlı coğrafyasında meydana gelen değişimleri yansıtan eserler geri planda kalmıştır. Bu da sömürgecilik sonrası araştırmalarında önemli bir eksikliktir.

İmparatorluk, kolonyalizm ve emperyalizm kavramları; Batı Avrupa dışında kalan ülkeler, topraklar ve toplumlar üzerinde uygulanan sistemli bir siyasete işaret eder. Bu sistem, merkez ile çevre arasındaki mutlak bir ötekileştirme üzerine kuruluydu; imparatorluk ana vatanı ile uzaktaki sömürge toprakları kalın çizgilerle birbirinden ayrılmaktaydı. Sömürge topraklarında yaşayan bir yerlinin, sömürgeci ana vatanı ile ilişki kurabilmesi için ötekileştirme sınırını aşması gerekiyordu. $\mathrm{Bu}$ da asimilasyon kavramının çok yönlü olarak tartışılması gerektiğini gösterir. Hâlbuki Osmanlı toprakları için aynı durumdan bahsedemeyiz. Osmanlı coğrafyasındaki değişim sürecinde uzak topraklardan Anadolu’ya yönelen göçler, imparatorluklar arasındaki sistem farklılıklarına işaret eder. Merkez ve çevre ilişkisinde olduğu gibi mutlak bir ötekileştirme ile birbirinden ayrılmadığı için, Osmanlı milletleri, Anadolu coğrafyasını kendileri için ana vatan olarak görmüşlerdir. Farklı eserlerden takip edebileceğimiz bu ilişkilerin ortaya çıkarılması ve yorumlanması, tarihimizle ilgili tanımları oryantalist hegemonyadan kurtaracaktır.

Modern çağda Batı Avrupa imparatorlukları benzer özelliklere sahiptir. Çarlık Rusya'sını da bu kategoriye dâhil edebiliriz. Portekiz, İspanya, İngiltere, Fransa, Belçika ve Rusya; imparatorluk özellikleri itibarıyla Osmanlı'dan ayrılırlar. Anadolu'ya yönelen göçler, din ve dil siyaseti açısından Osmanlı'nın Batı Avrupa imparatorluklarından farklı olduğunu gösterir. Osmanlı milletlerinin Anadolu topraklarında yabancılık çekmediği, bu milletlerin açısından ana vatan kavramının diğer imparatorluklara göre farklı olduğu açıktır. Propaganda amaçlı kavram ve yaklaşımlar bir kenara bırakıldığında Osmanlı topraklarında ötekileştirme siyasetinin uygulanmadığı ortaya çıkar. Osmanlı, Balkanları kaybettiğinde Müslüman unsurların Türklerle birlikte Anadolu’ya sığınmaları önemlidir. Müslüman olan gayr-i Türk unsurların, aslî vatanlarını terk ederek Anadolu'ya yönelmeleri, düşünce dünyasında ötekileştirmeye dayalı bir ilişki biçiminin olmadığını gösterir. Bu, Müslüman olmayan unsurlar için de geçerlidir. Onlar da Osmanlı topraklarını ve özellikle Anadolu'yu yurt bellemişlerdir.

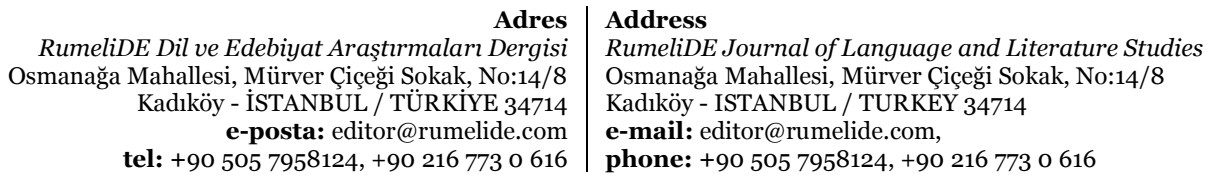


Buna karşın Çarlık Rusya'sının hâkim olduğu coğrafyanın gayr-i Rus milletleri Petersburg ve Moskova gibi şehirleri vatan olarak görmemişlerdir. Aynı şekilde Kenyalının veya Cezayirlinin Londra veya Paris’i anavatanı olarak görmesi de söz konusu edilemez.

Osmanlı devletinin dağılma sürecinde, imparatorluk coğrafyasındaki yeni devletler, sınırları belirlenmiş bir vatan fikri üzerine bina edilmedi. Fakat sömürgeci imparatorlukların ötekileştirici uygulamalarının bir sonucu olarak, sömürge toplumlarında sınırları sert çizgilerle belirlenmiş bir vatan duygusu gelişmiş ve o vatana duyulan sevgi ve özlem çok güçlü bir şekilde ifade edilmiştir. Osmanlı yönetiminde Arap coğrafyası için uzun zaman mevcut olmayan milliyetçi eğilimler, İngiltere ve Fransa'nın manda yönetimlerinde hızla yükselişe geçmiştir. Bu farklılığın dinî kavramlarla izah edilmesi yanıltıcı olabilir. İngiltere ve Fransa gibi ülkelerin ötekileştirici uygulamalarından beslenen karşıtlık, milliyetçi veya dinî niteliklere bürünmüştür. Nitekim İngiltere'nin Irak’ta tatbik ettiği yönetim sisteminde yerel dinamikler ön plana çıkınca milliyetçi ve dinî karşıtlıklarda yumuşama olduğu görülür.

\section{Osmanlı coğrafyasında büyük göçlerin edebiyatımıza yansıması}

Birinci Dünya Savaşı ve sonrasında gelişen hadiselerin edebiyata yansıma biçimi ifade ettiğimiz farklılıklar açısından önemlidir. Bilindiği gibi büyük savaşın sonunda galip devletler tarafindan desteklenen Yunanistan, Batı Anadolu'yu bir süre işgal etmişti. İzmir, 9 Eylül 1922'de işgal kuvvetlerinden kurtarıldı. Türkiye için Kurtuluş Savaşı'nın bir aşaması olarak kabul edilen olayların Ernest Hemingway tarafından "İzmir Rıhtımında" adlı öyküde katliam olarak tasvir edildiği belirtilmiştir (Gerward, 2018: 15). Kuşkusuz bu, ideolojik bir tutumdur. Hemingway'in, bir döneme damgasını vuran "büyük savaş"ın yol açtığı husumetleri, geleceğe taşıyarak, yeni husumetlere zemin teşkil edecek şekilde kullandığını söyleyebiliriz. Zaten oryantalist önyargı tam olarak budur. Hemingway ve onun tarafından temsil edilen Batı medeniyeti için edebiyat ve sanat, "öteki”yi yeniden tanımlamak için bir araca dönüşmüştür. Oryantalist önyargının şekillendirdiği bir zihniyet dünyası Hemingway'in ideolojik tutumunu kolaylıkla kabullenecektir. Böylelikle geçen asırların Türk imgesi yeniden üretilecektir. Hemingway'in kıyıa yakın bir yerde, bir geminin güvertesinden bakarak rıhtımda yaşananları katliam olarak tanımlaması, ötekileştirmenin boyutlarını gösteren önemli bir örnektir.

Yahya Kemal Beyatll, Faruk Nafiz Çamlıbel, Reşat Nuri Güntekin, Refik Halit Karay gibi devrin dönüşümlerine tanıklık eden şair ve yazarların eserleri, Osmanlı'dan Cumhuriyet'e geçişin sorunlarını işaret etmeleri bakımından da kıymetlidir. Hemingway gibi aynı dönemleri anlatan Faruk Nafiz, "Han Duvarları" şiirinde "büyük savaş”tan memleketine dönen, hasta ve yorgun Maraşlı Şeyhoğlu Satılmış’a şunları söyler: "Artık bahtın açıktır uzun etme arkadaş! / Ne hudut kaldı bugün, ne askerlik, ne savaş;” (Kaplan, 1984: 15).

$\mathrm{Bu}$ mısralarda savaştan yeni çıkmış bir milletin hayat ve öteki ile ilgili düşüncelerini görebiliriz. Coğrafya, vatan, öteki, savaş ve barış kavramlarının anlamları afakî olarak belirlenmemelidir. Edebî eserlerin her dönemde yeniden yorumlanmasıyla dikkatlerden kaçmış birtakım hususlar gün yüzüne çıkarılabilir. Bahsettiğimiz kavramlar için de benzer bir durum geçerlidir. Namık Kemal ve Ahmet Mithat Efendi'nin Silistre ve Musul'undan sonra Çamlıbel'in kahramanı Anadolu'da bir şehir olan Maraş’a döner. Hemingway dışarıdan baktığı bir savaşı, oryantalist bir yargıya malzeme hâline getirirken Faruk Nafiz, kahramanına sıradan hayatını yaşama tavsiyesinde bulunur. Fakat savaş yorgunu Şeyhoğlu, memleketine ulaşamadan eski bir handa ölür. Bu ölüm hadisesini, geçmişin bütün

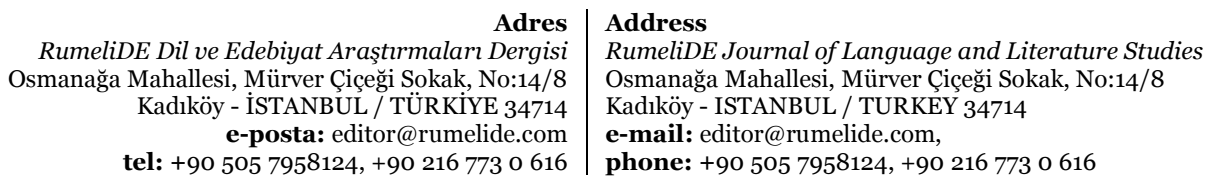


acı hatıralarının eskiyi çağrıştıran bir handa toprağa verilmesi olarak yorumlamak mümkündür. On yılını farklı cephelerde geçirdikten sonra yorgun ve hüzünlü bir şekilde, eve dönüş yolunda hastalığa yenilen asker ile şairin hiç karşılaşmaması, acı dolu geçmiş ile yeni hayat arasındaki zitlı̆̆a işaret eder. Adeta yeni bir hayata vurgu yapılmak istenmiştir. Bu iki örnek Çamlıbel ile Hemingway'in "ben ve öteki” hakkında oldukça farklı ve zıt tutumlara sahip olduğunu gösterir.

Faruk Nafiz’in realizmi (Kaplan, 1984: 18) ile devrin siyasî şartları arasında doğrudan ilişki kurabiliriz. Yeni bir dünya kurulmuş ve Osmanlı coğrafyasının kaybıyla neticelenen büyük savaştan sonra yeni bir devlet ortaya çımıştır. Coğrafî daralma ya da kopuş, nüfus hareketliliklerini beraberinde getirmiş ve Balkanlardan Anadolu'ya muazzam bir göç yaşanmıştır. Türkiye ile Arap coğrafyası arasında sınırlar oluşturulmuştur. Bu olağanüstü değişimlerden sonra şairin bakışlarını "göğü, toprağı ve çıplak ağaçları sarı" Anadolu bozkırlarına çevirmesi tabiî bir sonuçtur. Bu, mağlubiyet ile ortaya çıkan zaruretleri kabullenme anlamına gelen realist bir tavır olarak yorumlanabilir fakat aynı zamanda hayat ve öteki ile alakalı daha genel bir dünya görüşünün yansıması olarak da görülebilir. Faruk Nafiz'in "Han Duvarları" şiiri, toplumsal hafızada derin izler bırakan bu coğrafî hareketliliği yansıtan en önemli eserlerdendir.

\section{“Eskici” öyküsü ve coğrafya algısında değişim}

İmparatorluk coğrafyasında yaşanan daralma, kopuş ve nüfus hareketliliklerini göstermesi açısından Refik Halit Karay'ın “Eskici” adlı küçük öyküsü (Karay, 2000: 10-15) bu makalenin esas konusunu teşkil eder. Yazar, 1938'de yayımlanan (Aktaş, 1986: 72) bu kısa öyküde Hasan adlı küçük bir çocuğun hüzün verici hikâyesini anlatılır. "Eskici”yi şöyle özetleyebiliriz:

Anne ve babası vefat eden Hasan, akrabaları tarafından İstanbul'dan Filistin'in ücra bir köşesine gönderilir. Hasan, gemi yolculuğu ile İstanbul'dan ve ana dilinden uzaklaştıkça içinde bulunduğu durumu kavramaya başlar ve Arapça konuşulan yerlerde içine kapanır. Hayfa'da gemiden inerek yolculuğa trenle devam eder. Onu bir istasyonda halası karşılar ve yaşamına devam edeceği eve götürür. Hasan'ın suskunluğu evde de devam eder. Bir gün evin avlusuna yaşlı bir eskici gelir. Hasan, farkında olmadan, eskici ile Türkçe konuşmaya başlar. Bir sebeple ana vatanından ayrılmak zorunda kalan bu yaşlı Türk ile ana dilinde konuşmaktan oldukça memnun kalır. Eskici, avluda tamir işlerini bitirince evden ayrılır ve Hasan bir daha ana dilinde konuşamayacak olmaktan dolayı çok üzülür.

Refik Halit Karay'ın küçük kahramanı, Osmanlı coğrafyasının dağılma sürecindeki göçlerden farklı olarak Anadolu'nun dışına yönelir. Hasan'ın gönderildiği yer tesadüfen seçilmiş bir bölge veya şehir değildir. Birinci Dünya Savaşı'nın sonuna kadar Osmanlı’nın parçası olan Filistin, İngiltere'nin manda yönetimi altında kolonyalist bir istilaya maruz kalır. Manda yönetimi altındaki diğer bölgelerden farklı olarak Filistin'de demografik yapı da değişime uğrar. Avrupa'nın farklı bölgelerinden yoğun göçler neticesinde Filistin'de koloniler oluşur. Savaş döneminde Filistin'de Yahudi nüfusunun iki katına çıktığı belirtilmiştir (Armaoğlu, 1991: 25).

Osmanlı coğrafyasında ortaya çıkan yeni devletlerin bir kısmı manda yönetimleri altındaydı. Osmanlı döneminde bir vilayet olan Suriye'de birkaç devlet doğdu. Refik Halit Karay, Millî Mücadele dönemindeki siyasî duruşu sebebiyle yüz ellilikler listesine alınmış ve yurt dışına sürgüne gönderilmişti (Aktaş, 1986: 34). Sürgündeki yaşamını işte bu eski Suriye vilayeti sınırlarında geçiren Karay’ı, Osmanlı coğrafyasında meydana gelen daralma, kopuş ve dağılma sürecini yansıtma biçimi

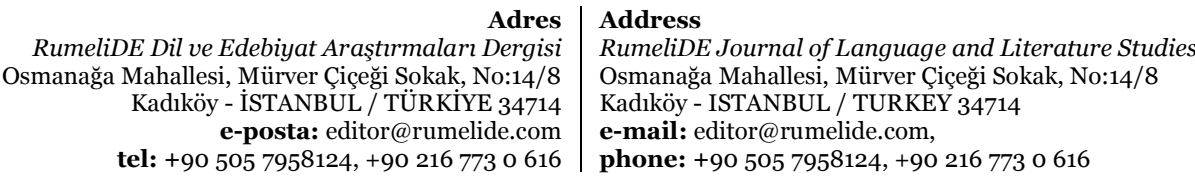


oldukça önemlidir. Eski Suriye vilayeti büyük ölçüde Fransa hâkimiyetine geçmiş ve manda yönetimi kurulmuştu.

Refik Halit Karay'ın sürgün yıllarında Suriye'de Fransız manda yönetimine karşı muhalif hareketler yükselişe geçer. Bunlardan biri isyan boyutundadır ve 1925'te başlar (Provence, 2005: 13). Refik Halit de kalemi ve ilişkileri ile muhalefet hareketlerine katılır. Yazar ilk önce Türkçe Doğru Yol gazetesinde yazmaya başlar fakat bu gazetenin ideolojisinden memnun olmadığı için 1928'den itibaren milliyetçi çizgideki Vahdet gazetesine geçer. Vahdet'in edebî müdürlüğünü de yapan Refik Halit, Ankara'dan da yardım görür. Yazarın, Halep’te yaşadığı bu yıllarda yazılarıyla direniş hareketlerine destek verdiği anlaşılmaktadır. Bu dönemde Ankara ile temas hâlinde olan Karay, Hatay'ın bağımsızlığını kazandığı zamana kadar Suriye'deki mücadelesini devam ettirir. Aynı yllarda Karay, Hataylı Türk gençleri ile de temasa geçer (Aktaş, 1986: 35-36). "Eskici”nin yayımlandığı yıl olan 1938'de Refik Halit Karay, Türk vatandaşlığına kabul edilir ve ana yurda döner. Belirtilen tarihten bir yıl sonra Hatay, Türkiye’ye dâhil olur. Siraladığımız bu tarihî hadiseler "Eskici”nin anlam zemini olarak görülebilir. Coğrafyanın değişimi Birinci Dünya Savaşı’ndan sonra da devam etmiştir. Coğrafî değişim süreci Suriye’yi de derinden etkilemiştir.

\section{Hasan'ın İstanbul'dan ayrılması ve coğrafî bölgelerin ana vatandan kopması}

Öykünün en etkileyici sahnelerinden biri Hasan ile eskicinin buluştuğu an olduğu için okuyucunun dikkati ana dili üzerine yoğunlaşır. Refik Halit Karay'ın "Eskici" Hikâyesi Üzerine Bir İnceleme (Çağın, 2005: 73-74) başlıklı makalede insan ve tabiat unsurlarının önemine işaret edilmiş ve tabiatın gurbet duygusunu anlatabilmek açısından çok başarılı bir şekilde tasvir edildiği söylenmiştir. Öyküde eskicinin mekândan ayrılma sahnesini gurbet duygusunun ötesine taşıdığımızda Karay'ın mekânlar arasında kurduğu ilişki çok daha belirgin hâle gelir. Bu da öykünün farklı anlam katmanlarını keşfetmemizi sağlar. Aslında öyküde mekândan ayrılma sahnesi iki defa geçmektedir. İlkinde Hasan, bir mekân olarak İstanbul'dan ayrılıp Filistin'e gitmişti. İlk ayrılık sahnesinde Hasan'ın acıyı fark etmemesi, mekândan ayrılma sahnesinin dikkatlerden kaçmasına yol açar. İmparatorluk coğrafyası, savaş, coğrafyanın parçalanması, coğrafî bölgelerin ve şehirlerin vatandan uzaklaşması bağlamında düşündüğümüzde Hasan'ın bir mekân olarak İstanbul'dan ayrılması çok daha anlamlı hâle gelir. Çocuk, anne ve babasıyla birlikteyken bir ailenin üyesiydi. Coğrafyanın tamamını bir büyük aileye benzettiğimizde, anne ve babanın ölümüyle çocuğun mekândan uzaklaşması, okuyucuda kopma, dağılma hissi uyandırır.

“Eskici”de olayların geçtiği ilk mekân İstanbul'dur. Bu şehir imparatorluk coğrafyasının başkentiydi. Aileyi bir arada tutan mekânda yaşayan anne ve babanın ölümü ile çocuğun İstanbul'da yaşamasının imkânı kalmamıştır. Bu sebeple yakın çevresi onu Filistin'deki akrabalarının yanına gönderir. Aynı geniş ailenin bir parçası olan halanın Filistin'de yaşaması, öyküde ailenin bir mecaz olarak kullanıldı̆̆ını gösterir. Coğrafyanın parçaları büyük ailenin üyeleri olarak kabul edilebilir. Hasan, "uzak akrabaları ve konu komşu” tarafından Filistin'de yaşayan halanın yanına gönderilmiştir. "Vapur rıhtımdan kalkıp tâ Marmara'ya doğru uzaklaşmaya başlayınca yolcuyu geçirmeye gelenler, üzerlerinden ağır bir yük kalkmış gibi ferahladılar.”(Karay, 2000: 10) cümlesini hem Hasan’ın bireysel macerası hem de coğrafyanın birbirinden kopuşu olarak yorumlamak mümkündür. Hasan ana vatanından koparken coğrafyamızın çözülme süreci devam ediyordu. Fakat yine de Hasan yakın akrabalarının yaşadığı Filistin'e gitmiş̧ir. Bu da emperyalist Batı Avrupa ülkelerinin sömürge topraklarıyla kurduğu ilişkiden tamamen farklı bir duruma işaret eder. Hasan'ın akrabaları Filistin'in

\footnotetext{
Adres | Address

RumeliDE Dil ve Edebiyat Araşttrmalar Dergisi $\quad$ RumeliDE Journal of Language and Literature Studies Osmanağa Mahallesi, Mürver Çiçeği Sokak, No:14/8 Osmanağa Mahallesi, Mürver Çiçeği Sokak, No:14/8 Kadıköy - İSTANBUL / TÜRKIYE 34714 Kadıköy - ISTANBUL / TURKEY 34714 e-posta: editor@rumelide.com e-mail: editor@rumelide.com, tel: +90 505 7958124, +90 2167730616 phone: +90 505 7958124, +90 2167730616
} 
aslî unsurlarıdır. Hasan, halaya ve yeni mekâna uyum göstermekte zorlansa da oranın yabancısı değildir.

\section{"Eskici"de mecazlar}

Hasan, Filistin’in ücra bir yerinde yaşayan halasına ulaşır fakat vapurda başlayan suskunluğu uzun bir müddet devam eder. Öykünün zamanı açıkça belirtilmemekle birlikte yazarın hayat hikâyesinden hareketle Hasan'ın çocukluk yıllarında Filistin'de İngiliz manda yönetiminin geçerli olduğunu düşünebiliriz. Onun Hayfa'da bir trene binmesi ve eskici ayrıldıktan sonra "bir daha Türkçe konuşacak adam bulamayacak” olması, öykünün zamanı hakkında tahminde bulunmamızı kolaylaştırır. Hayfa'da tren istasyonu 1905'ten sonrasına, Türkçe konuşacak adamın bulunamayacak olması da Birinci Dünya Savaşı'ndan sonraki zamana işaret eder. Bu ise yazarın ve öykünün zamanının örtüştüğünü gösterir. Öyküde Türkçe konuşacak bir adamın olmayacağının ifade edilmesiyle kopma ve uzaklaşmanın okuyucu üzerindeki etkisi artırılmak istenmiştir. Filistin coğrafyasında Türkçenin artık konuşulmaması, aynı zamanda, nihayete eren Osmanlı hâkimiyetini ifade eder. Fakat Hasan'ın yaşadığı ortam, Filistin’in ücra bir yeri olması sebebiyle yine de büsbütün kozmopolit değildir. Eskiyi temsil eden ihtiyar ile yeniyi temsil eden çocuğun yalıtılmış bir atmosfer olan avluda karşlaşarak ana dilleri üzerinden irtibat kurması öykünün kurgusu bakımından önemlidir. "Gurbet bu iki insanı birleştirmiştir” (Balkan, 2010: 68). Türkçe, uzaktaki bir yerde eski ile yeniyi birbirine bağlamıştır. Bu, coğrafyamızın birbirinden kopan parçaları arasında bir bağ kurma anlamına da gelebilir. Sömürgecilik sisteminin tahrip ettiği en önemli unsurlardan biri dildir. Zamanla yerel diller baskıya dayanamaz ve sömürge topraklarında galiplerin dili hüküm sürmeye başlar.

Hatay'ın Türkiye'ye katılma mücadelesi bağlamında ele aldığımızda çocuk ve yaşlı adamın buluşması çok daha anlamlı hâle gelir. Çağın'ın (2005) ana dili üzerindeki vurgusu önemlidir, zira zorunlu coğrafî ayrılığın hüznü ancak ana dilinden uzakta kalmakla anlatılabilirdi. Hasan'ı İstanbul'dan halasının yanına gönderenler, "üzerlerinden ağır bir yük kalkmış gibi” ferahlamışlardır. Bu, coğrafî̀ kopuş karşısında takınılan bir tavır olarak nitelenebilir. Ana gövdeden koparılmış coğrafî parça, İstanbul'da kalanlar için bir yük olmaktan çıkacaktır. Fakat onlar Hasan'ı İstanbul'dan göndermekle yükten kurtulmuş olsalar da Hasan ve onun temsil ettiği coğrafya, Türkçe üzerinden Anadolu ile bağını yeniden kurar. Filistin, Osmanlı coğrafyasının parçalarını temsil eden önemli mekânlardan biridir. Bu bölge de Birinci Dünya Savaşı’ndan sonra kolonileştirilmiştir. Hatay da ana vatandan koparılmış parçalardan biridir. “Eskici”nin Hatay'ın Türkiye’ye katılma mücadelesinin devam ettiği bir dönemde yayımlanması dikkat çekici bir ayrıntıdır. Bu önemli hadiseyi de öykünün anlam zeminini oluşturan unsurlar arasına dâhil edebiliriz.

Hasan’ın, ana dili üzerinden yaşadığı yoğun gerilimi, Arapça'ya karşı milliyetçi bir tepki olarak düşünmek doğru olmaz. Sürgündeki yaşamının büyük bölümünü Suriye'de geçiren yazarın, Arapların çoğunlukta olduğu bir yerde Arapçaya tepki göstermeyeceği açıktır. Hâlbuki öyküde Arapçaya karşı olumsuz bir tavır takınılmıştır. Bunun dil milliyetçiliğinden farklı bir duruma işaret ettiğini söyleyebiliriz. Hasan, Arapçayı anlamaya başladığı hâlde konuşmak istemez. Eskicinin avludan ayrılma sahnesinde Hasan'ın "bir daha Türkçe konuşacak adam bulamayacağı" dile getirilmişti. Hasan, Arapça konuşmaya başlasaydı yeni şartlara uyum göstermiş olacaktı. Arapça'nın yeni coğrafî ve siyasî şartları temsil ettiğini düşündüğümüzde Hasan'ın inatçı tavrı anlam kazanır. Öykünün yazıldığı dönemde Türkçe Vahdet gazetesinde Türkiye çizgisindeki yazılar, Arapça karşısındaki tavrını izaha imkân sağlar. Refik Halit'in eserlerinde "kolonyalizm ve ona bağlı olguların yazarın ideolojik yönsemelerinin ışığında doğrudan irdelenmesine şahit olunmadığı”; kişi, mekân ve olay örgüsü

\footnotetext{
\begin{tabular}{r|l} 
Adres & Address \\
RumeliDE Dil ve Edebiyat Araştırmalar Dergisi & RumeliDE Journal of Language and Literature Studies
\end{tabular} Osmanağa Mahallesi, Mürver Çiçeği Sokak, No:14/8 Osmanağa Mahallesi, Mürver Çiçeği Sokak, No:14/8 Kadıköy - İSTANBUL / TÜRKIYE 34714 Kadıköy - ISTANBUL / TURKEY 34714 e-posta: editor@rumelide.com e-mail: editor@rumelide.com, tel: +90 505 7958124, +90 2167730616 phone: +90 505 7958124, +90 2167730616
} 
bağlamında tasvirî bir yaklaşım söz konusu olduğu (Güngör, 2018: 124) yönündeki görüşleri ihtiyatla karşılamak gerekir. Osmanlı sonrasında ortaya çıkan siyasî yapılar üzerine yapılacak yeni çalışmalar, edebî eserlerin farklı açlardan yeniden incelenmesine kaynaklık edebilir. Refik Halit kolonyalist yönetimi yaşayarak tecrübe etmişti. Üstelik üretken bir yazar olarak hem İngiltere hem de Fransa sömürge sisteminde yaşarken eserler vermişti. Bu da onun eserlerinin yeni yorumlara imkân vereceğini gösterir. İdeolojik eğilimleri belirli fikirlerin ifade edilmesi ile sınırlandırmamak gerekir. Belirli bir davranış veya tepkiyi ideolojik bir çerçeve içine dâhil etmek mümkündür. Dolayısıyla Hasan’ın Türkçe konuştuğunda yaşadığı mutluluğu ideolojik bir çerçeveye dâhil edebiliriz.

\section{Sonuç}

19. yüzyılın sonları ve 20. yüzyılın başlarında küresel ve yerel düzeylerde büyük değişimler yaşandı. Değişimlerin coğrafyamızda çeşitli sahaları etkilemesi ve dönüştürmesi kaçınılmazdı. Bunları belirlemek ve etkilerini edebî eserleri veri alarak izlemek yeni sonuçlara ulaşmak açısından önemlidir. Büyük bir imparatorluk coğrafyasının dağılması ve yerinde birçok devletin ve yeni siyasî yapıların belirmesi edebî eserlerin de konusudur. Edebiyatçlların büyük değişim ve dönüşümlerden etkilenmesi kaçınılmaz bir durumdur. Refik Halit Karay, bahsettiğimiz değişimlerin yaşandığı coğrafî bölgelerde bizzat bulunmuş ve o dönemlerde eserler vermiştir. Özellikle Suriye'de yaşadığı dönemde verdiği eserlerin Türkiye'nin ve coğrafyamızın bugününü de ilgilendirdiğini söyleyebiliriz. Bu makalede göstermeye çalıştığımız gibi onun eserlerinden biri olan "Eskici", coğrafî değişimlerin etkilerini gösterir niteliktedir. Osmanlı'nın kaybettiği topraklardan Anadolu’ya doğru yoğun bir göç yaşanırken bu öykünün iki önemli kahramanı dışarıya doğru gitmiştir. Bu açıdan “Eskici”nin yeni Türkiye'nin sınırları dışında yaşayan ve Anadolu ile doğrudan bağlara sahip unsurlara vurgu yaptığını söyleyebiliriz. Bu da "Hariçteki Türkler" olgusunun edebî eserlerle yansıtıldığına işaret eder.

Yazarın Fransız manda yönetiminde yaşadığı dönemden izler taşıyan diğer eserleri de farklı yorumlara açıtır. Karay'ın eserlerinin Doğu-Batı ilişkileri, sömürgecilik, oryantalizm ve postkolonyalizm gibi edebiyat araştırmalarında göz ardı edilemeyecek kavramlar için zengin bir kaynak niteliğinde olduğunu söyleyebiliriz. Bu, benzer niteliklere sahip başka yazarların eserleri için de geçerlidir. Nitekim makalede bunlardan bazılarına sınırlı düzeyde de olsa değindik ve edebî eserlerin bahsettiğimiz kavramlar çerçevesindeki araştırmalara kaynaklık edeceğini göstermeye çalıştık. Bu karşılaştırmayı hem Doğu-Batı hem de yerel düzeydeki ilişkiler bağlamında düşünmek gerekir. Makalemizde edebî eserlerin her iki düzey için önemsenmesi gerekli bir kaynak olduğu gösterilmiştir.

Osmanlı coğrafyasında meydana gelen değişimler, düşünce dünyamızda da derin izler bırakmıştır. 20. yüzyılda ideolojik çatışmaların en üst seviyeye çlkmasıyla değişimlerin gücü arasında doğrudan bir bă̆ olduğu görülür. Düşünce dünyamızı şekillendiren büyük değişimlerin ideolojileri etkilemesi de kaçınılmaz bir sonuçtur. Refik Halit Karay ve benzer yazarların edebî eserlerini ideolojilerin tarihini aydınlatmak açısından da ele alabiliriz. Ana vatandan uzakta dil üzerinden buluşma, "Eskici”nin en etkili sahnelerinden biridir. Bu romantik bir üsluptur ve yazarın ideolojik görüşünü anlamamızı sağlar. Refik Halit Karay'ın ve benzer yazarların eserlerinden hareketle yapılacak yeni çalışmalar, düşünce dünyamıza önemli katkılar sağlayacaktır.

\section{Kaynakça}

Aktaş, Ş. (1986). Refik Halit Karay, Ankara: Kültür ve Turizm Bakanlığı.

Armaoğlu, F. (1991). Filistin meselesi ve Arap-İsrail savaşları (1948-1988), Ankara: Türkiye İş bankası kültür.

\footnotetext{
RumeliDE Dil ve Edebiyat Araștırmaları Dergisi Osmanağa Mahallesi, Mürver Ciceği Sokak, No:14/8 Kadıköy - İSTANBUL / TÜRKIYE 34714 e-posta: editor@rumelide.com tel: +90 505 7958124, +90 216773 o 616 
Balkan, A. (2010). Refik Halit Karay'ın eserlerinde sosyal tenkit (Yayımlanmamış doktora tezi), Marmara Üniversitesi Türkiyat Araştırmaları Enstitüsü, İstanbul.

Çağın, Ş. (2005). Refik Halit Karay’ın "Eskici” hikâyesi üzerine bir inceleme. Türklük Bilimi Araştırmaları, (18), 69-81.

Gerwart, R. (2018). Mağluplar birinci dünya savaşı neden bitmedi? 1917-1923 (Çev: Yüksel Taşkın), İstanbul: Doğan.

Güngör, B. (2018). Postkolonyalizm ve edebiyat Türk edebiyatında sömürgeciliğe bakış. Ankara: Hece.

Kandemir, F. (1991). Medine müdafaası peygamberimizin gölgesinde son Türkler, İstanbul: Nehir.

Kaplan, M. (1984). Şiir Tahlilleri II. İstanbul: Dergah.

Karay, R. H. (2000). Gurbet hikâyeleri. İstanbul: İnkılap.

Provence, M. (2005). The great syrian revolt and the rise of arab nationalism. Austin: University of Texas Press.

Said, E. W. (1998). Kültür ve emperyalizm kapsamlı bir düşünsel ve siyasal sorgulama çalışması (Çev. Necmiye Alpay). İstanbul: Hil.

Said, E. W. (1991). Oryantalizm sömürgeciliğin keşif kolu (Çev. Selahaddin Ayaz). İstanbul: Pınar.

Young, R. J. (2016). Postkolonyalizm tarihsel bir giriş (Çev. Burcu Toksabay Köprülü, Sertaç Şen), , İstanbul: Matbu. 